\title{
Herne ja rypsipuriste teuraaksi kasvatettavien hereford-hiehojen valkuais- lähteenä vieroituksen jälkeisessä ruokinnassa
}

\author{
Merja Manninen $^{1)}$, Arja Nykänen ${ }^{2)}$, Tarja Musikka ${ }^{3)}$ ja Pentti Ojajärvi ${ }^{4)}$ \\ ${ }^{1)}$ MTT, 31600 Jokioinen, merja.manninen@mtt.fi \\ ${ }^{2)}$ MTT, 51900 Juva, arja.nykanen@mtt.fi \\ ${ }^{3)}$ Keski-Karjalan kehittämis- ja tietokeskus KETI, 82430 Puhos, tarja.musikka@pp.inet.fi \\ ${ }^{4)}$ Pohjois-Karjalan ammattikorkeakoulu, 82430 Puhos, pentti.ojajarvi@ncp.fi
}

\section{Tiivistelmä}

Hiehojen ongelmana on ruhojen rasvoittuminen alhaisissa teuraspainoissa. Teurastamoiden tavoitteena on saada ruhoja, joissa pintarasvan määrä on vähäinen ja teuraspaino korkea. Näiden tavoitteiden saavuttamiseksi on ruokintaan suositeltu lisävalkuaista erityisesti loppukasvatuksen ajaksi. Luonnonmukaisessa tuotannossa sallittuja lisävalkuaislähteitä ovat herne ja rypsipuriste. Tämä tutkimus selvitti herneen ja rypsipuristeen vaikutukset hereford (hf)-hiehojen kasvuun sekä ruhon ja lihan laatuun, kun väkirehuseoksen valkuaispitoisuus oli joko $17 \%$ tai $20 \%$.

Kokeeseen otettiin 20 hf-lehmävasikkaa, jotka painoivat kokeen alkaessa keskimäärin 258 kg. Koe tehtiin Pohjois-Karjalan ammattiopisto Kiteen opetusmaatilan navetassa. Luonnonmukaisesti viljelty herne ja siirtymävaiheen ohra olivat Kiteen opetusmaatilan viljelyksiltä. Rypsipuristeen kokeeseen toimitti Mildola Oy. Kokeessa oli kaksi väkirehuseosta, ohra+rypsipuriste (Rp) tai ohra+herne (He). Väkirehuseoksen valkuaispitoisuus oli keskinkertainen (K, 17 \% KA:ssa) tai runsas (R, 20 \% KA:ssa). Hiehot saivat väkirehuseosta 2 kg KA/pv koko kokeen ajan. Karkearehuna oli luonnonmukaisesti viljelty apilapitoinen säilörehu vapaasti. Teuraspainotavoite oli $210 \mathrm{~kg}$. Hiehot teurastettiin Kiteen opetusteurastamossa.

Säilörehun KA-pitoisuus oli 300 g/kg ja D-arvo 74,9 \%. KA-kilo sisälsi raakavalkuaista 128 g ja OIV:sta 90 g. Ohran valkuaispitoisuus oli 152 g/kg KA, OIV-pitoisuus 105 g/kg KA ja energiapitoisuus 1,08 RY/kg KA. Vastaavat arvot rypsipuristeelle olivat 361, 157 ja 1,08 ja herneelle 228, 122 ja 1,15. Väkirehu-\% oli keskimäärin 28. Dieetin valkuaispitoisuus oli K-ruokinnoilla keskimäärin 13,8 \% ja R-ruokinnoilla 14,6 \%. Säilörehun syönti oli keskimäärin 4,93 kg KA/pv. Kaikki hiehot saavuttivat tavoiteteuraspainonsa. Koe kesti keskimäärin 129 pv. RpR-hiehoilla kasvatuskausi oli keskimäärin 18 pv lyhyempi kuin RpK-hiehoilla. Väkirehuseoksen runsaampi rypsipuristepitoisuus tehosti kasvua 184 g/pv, kun vaikutus herneellä oli lievästi päinvastainen. Nettokasvu oli keskimäärin 656 g/pv. Kaikki ruhot rasvoittuivat. Ruokintojen vaikutus arvopalasaantoihin oli marginaalinen. Rasvaa rypsipuristeella ruokitun hiehon ruhonpuolikkaasta leikattiin keskimäärin $2 \mathrm{~kg}$ enemmän kuin herneellä ruokitun hiehon ruhonpuolikkaista. Väkirehun alhaisempi valkuaispitoisuus rypsipuristeella ruokittaessa paransi lihan mehukkuutta, kun vaikutus herneellä oli päinvastainen. Kaikkien ruhojen tervaliha-\% oli 0.

Hiehojen kasvu oli keskimäärin 1125 g/pv ja ne saavuttivat teuraspainotavoitteensa keskimäärin 10,5 kuukauden iässä. Dieettien kokonaisvalkuaispitoisuus jäi alle 15 \% vaikka väkirehuseos sisälsi 20 $\%$ raakavalkuaista. Kaikki ruokinnat täyttivät luonnonmukaisen tuotannon vaatimuksen väkirehukarkearehu-suhteesta. Rypsipuriste osoittautui hernettä paremmaksi valkuaislähteeksi paremman tuotantovaikutuksensa vuoksi. Herneen saatavuus ja hinta määrännevät käytännössä sen käyttömahdollisuudet lihanautojen ruokinnassa.

Asiasanat: herne, hieho, luonnonmukainen tuotanto, naudanlihantuotanto, ruokinta, valkuainen 


\section{Johdanto}

Rypsi on Suomessa eniten tutkittu nautakarjan lisävalkuaisen lähde. Kotimaisten valkuaislähteiden merkitys nautojen ruokinnassa on korostunut viime vuosina mm. BSE:stä ja gmo-soijasta käydyn keskustelun johdosta (Vanhatalo ym. 2004). Luonnonmukaisen tuotannon lisääntymisen myötä kiinnostus rypsin lisäksi myös muihin potentiaalisiin kotimaisiin valkuaislähteisiin on lisääntynyt. Yhtenä tällaisena vaihtoehtona on nähty herneen käyttö nautojen ruokinnassa. Korkean tärkkelys- ja valkuaispitoisuuden lisäksi, valkuaista keskimäärin 23 \% kuiva-aineessa (KA), herne on myös energiapitoinen kuiva-ainekilon sisältäessä keskimäärin 1,15 rehuyksikköä. Herneen valkuaisen pötsihajoavuus on rypsija soijapuristetta suurempi (80 vs. 60 vs. 75 \%), mikä tulee huomioida ruokinnassa (MTT 2004). Viime vuosina puhtaan rehuherneen viljelyala on ollut Suomessa noin 5000 hehtaaria, josta $40 \%$ on ollut luonnonmukaisesti viljeltyä (TIKE 2003). Herneen viljely puhtaana kasvustona voi olla riskialtista varsinkin multavammilla mailla, sillä sen lakoontumisriski on suuri, mikä aiheuttaa sekä laadullisia että määrällisiä tappioita. Varsinkin luomutuotannossa hernettä viljellään yleisesti seoksena tukikasvin kanssa, joista yleisimmät ovat ohra ja kaura. Herneen viljelyn lisäämistä puoltaa sen kyky sitoa typpeä ilmasta Rhizobium-bakteerin avulla, jolloin kasvi on omavarainen typen suhteen ja sen esikasviarvo on hyvä. Herne saa myös valkuaiskasvituen.

Lypsylehmillä tehdyssä tutkimuksessa herne osoittautui rypsirouheen kanssa samanarvoiseksi valkuaisrehuksi arvioitaessa säilörehun syöntiä, maito-, rasva- ja valkuaistuotoksia sekä maidon koostumusta (Heikkilä ja Toivonen 1997). Toisaalta on myös osoitettu lypsylehmien maidontuotannon heikkenevän, kun rypsirouhe korvattiin kokonaan herneellä (Khalili ym. 2002). Tätä tulosta tukevat lypsylehmillä tehdyn fysiologisen kokeen tulokset (Vanhatalo ym. 2004). Siinä ohutsuoleen virtaavan ei-ammoniakkitypen määrä lisääntyi dieetin sisältäessä rypsirouhetta tai hernettä, mutta hernetäydennyksellä vähemmän kuin rypsitäydennyksellä. Friisiläis- ja ayrshire-sonneilla verrattiin kolmen pötsihajoavuudeltaan erilaisen valkuaislähteen, herneen, rypsirouheen ja urean, vaikutusta lihanautojen rehun käyttöön, kasvuun ja teurastuloksiin, kun karkearehuna oli heinä ja väkirehuna ohra tai kaura (Root 1995). Valkuaistäydennyksen tyyppi ei vaikuttanut syöntiin, kasvuun, teuraspainoon tai ruhojen luokittumiseen.

Vuonna 2004 teurashiehojen keskipaino oli maassamme 231 kiloa (Kallinen 2004). Hiehojen ongelmana on yleisesti ruhojen rasvoittuminen jo alhaisissa teuraspainoissa. Teurastamoiden tavoitteena on saada ruhoja, joissa pintarasvan määrä on vähäinen, lihakkuus hyvä ja teuraspaino korkea. Näiden tavoitteiden saavuttamiseksi on ruokintaan suositeltu lisävalkuaista erityisesti loppukasvatuksen ajaksi. Luonnonmukaisessa tuotannossa sallittuja lisävalkuaislähteitä ovat herne ja rypsipuriste.

Tämä tutkimus on jatkoa MTT:n, Pohjois-Karjalan ammattikorkeakoulun ja Kiteen oppimiskeskuksen kanssa yhteistyönä aiemmin tehdyille hiehokokeille (Rinne ym. 1998, Rinne ja Ojajärvi 1998, Manninen ja Ojajärvi 2000, Manninen ym. 2002, Manninen ym. 2004a ja 2004b). Tässä tutkimuksessa selvitettiin luonnonmukaisessa tuotannossa sallittujen valkuaislähteiden, herneen ja rypsipuristeen, vaikutukset hereford (hf)-hiehojen kasvuun sekä ruhon ja lihan laatuun, kun väkirehuseoksen valkuaispitoisuus oli joko keskinkertainen $17 \%$ tai runsas $20 \%$. Hiehot saivat väkirehua 2 kuiva-ainekiloa päivässä koko kasvatuskauden ajan. Karkearehuna oli luonnonmukaisesti viljelty, ensimmäisen niiton apilapitoinen säilörehu. Samanaikaisesti tämän tutkimuksen kanssa tehtiin MTT:n emolehmänavetalla vieroitetuilla hf-sonneilla koe, jossa väkirehuseoksen valkuaispitoisuus oli joko $17 \%$ tai $21 \%$. Tämä koe linkittyy tältä osin sonnien loppukasvatuskokeeseen ja hankkeeseen 'Laatulihaa tehokkaalla emolehmätuotannolla' (http://www.mtt.fi/tutkimus/talous/talous.html).

\section{Aineisto ja menetelmät}

\section{Eläinaines ja tuotanto-olosuhteet}

Kokeeseen otettiin 20 MTT:n emolehmänavetalla 21.3.-27.4.2003 syntynyttä hf-lehmävasikkaa, joiden isinä olivat hf-sonnit Innilän Leevi (12), Karjasuon Pölli (4) ja Karjasuon Paukku (4). Ennen koetta vasikat olivat emiensä kanssa laitumella ja kasvu syntymästä 29.9.2003 asti oli keskimäärin $1164 \mathrm{~g}$ päivässä. Vasikat eivät saaneet laitumella väkirehua. Kokeen alkaessa 15.10 .2003 vasikat olivat keskimäärin 193 (SD 10,4) päivän ikäisiä ja painoivat 258 kiloa (SD 17,9). Koe tehtiin Pohjois-Karjalan ammattiopisto Kiteen opetusmaatilan navetan yksilöruokintaparsissa. Eläimet punnittiin ja kuntoluokitettiin (Lowman ym. 1976) säännöllisesti. 


\section{Rehut ja ruokinta}

Luonnonmukaisesti viljelty Sunna-herne ja siirtymävaiheen Artturi-ohra olivat Pohjois-Karjalan ammattiopisto Kiteen opetusmaatilan viljelyksiltä. Herneen lannoitukseen käytettiin sian lietelantaa 20 t/ha ja ohran lannoitukseen sian- ja naudan kuivalantaa 24 t/ha. Mildola Oy toimitti kokeeseen rypsipuristeen. Kokeessa oli kaksi väkirehuseosta, ohra + rypsipuriste (Rp) tai ohra + herne (He). Väkirehuseoksen valkuaispitoisuus oli joko keskinkertainen (K, 17 \% KA:ssa) tai runsas (R, 20 \% KA:ssa). Hiehot saivat väkirehuseosta 2 kuiva-ainekiloa päivässä koko kasvatuskauden ajan.

Karkearehuna oli laakasiiloon 16.-18.6.2003 Kiteen oppimiskeskuksen luomulohkolta 2. vuoden kasvustosta tehty apilapitoinen, esikuivattu säilörehu (timotei $35 \%$ - nurminata $20 \%$ - apila $45 \%$ siemenseoksessa), korjuukoneina JF GCS 2800 D telaniittomurskain ja JF FCT 900 tarkkuussilppuri. Kasvusto ei saanut kevätlannoitusta. Säilöntäaineena käytettiin AIV 2 Plus -liuosta 5 l rehutonnille. Hiehot saivat säilörehua ja vettä vapaasti. Kivennäisenä käytettiin Luonnon Viher-Mineraa (Suomen Rehu Oy; Ca 84, P 34, Na 60 ja Mg 70 g/kg). Vitamiinitäydennystä ei annettu. Hiehojen teuraspainotavoitteeksi asetettiin $210 \mathrm{~kg}$. Säilörehusta analysoitiin MTT:llä KA, tuhka, raakaproteiini, neutraali detergentti kuitu (NDF, Van Soest ym. 1991) ja orgaanisen aineen in vitro-sellulaasisulavuus (Friedel 1990). Väkirehujen rehuarvot laskettiin kemiallisen koostumuksen perusteella (MTT 2004).

\section{Teurastus, ruhon ja lihan laatu}

Hiehot teurastettiin Kiteen opetusteurastamossa. Ruhot luokitettiin EUROP-luokituksen mukaisesti. Ruhon puolikkaan arvopalat ja erilleen leikattu rasva punnittiin. Ulkofileestä määritettiin loppu-pH 24 h teurastuksesta ja leikattiin pala, joka vakumoitiin Kiteellä ja toimitettiin pakastamatta LTK:een aistinvaraiseen arvosteluun ja konsistenssimääritykseen. Näytteet arvioitiin aistinvaraisesti noin kahden viikon kuluttua saapumisesta, johon saakka niitä säilytettiin kylmiössä $+8^{\circ} \mathrm{C}\left( \pm 2^{\circ}\right)$. Konsistenssi eli vastus lihapalaa leikattaessa määritettiin aistinvaraista arvostelua seuraavana päivänä.

\section{Tilastollinen käsittely}

Jokaisella käsittelyllä oli kolme Innilän Leevin, yksi Karjasuon Paukun ja yksi Karjasuon Pöllin tytärtä. Isän vaikutus huomioitiin mallissa. Käsittely-tekijät olivat faktoriaalisia eli muodostuivat kahden eri tekijän kombinaatioista (valkuaisen lähde; valkuainen ja väkirehuseoksen valkuaispitoisuus; pitoisuus). Analyysit suoritettiin SAS:n (1999) versiolla 8.2. varianssianalyysilla (GLM) käyttäen mallia: $\mathrm{y}_{\mathrm{ijk}}=\mu+$ Isä $_{\mathrm{k}}+$ Valkuainen $_{\mathrm{i}}+$ Pitoisuus $_{\mathrm{j}}+($ Valkuainen $\times$ Pitoisuus $) \mathrm{ij}+$ Virhe $_{\mathrm{ijk}}$

\section{Tulokset ja tulosten tarkastelu}

Säilörehun KA-pitoisuus oli keskimäärin 300 g/kg, pH 3,82, D-arvo 74,9 \%, syönti-indeksi 107 ja energiapitoisuus 1,02 RY/kg KA. KA-kilo sisälsi raakavalkuaista 128 g ja OIV:sta 90 g. Säilörehun Darvo oli erittäin korkea, mutta kesälle 2003 tyypillinen Pohjois-Karjalan alkukesän olosuhteissa. Ohran raakavalkuaispitoisuus oli korkea eli 152 g/kg KA, OIV-pitoisuus 105 g/kg KA ja energiapitoisuus $1,08 \mathrm{RY} / \mathrm{kg}$ KA. Vastaavat arvot rypsipuristeelle olivat 361, 157 ja 1,08 ja herneelle 228, 122 ja 1,15. Rasvaa rypsipuriste sisälsi kymmenkertaisesti herneeseen verrattuna (111 vs. 11 g/kg KA).

Väkirehuprosentti oli keskimäärin 28 (Taulukko 1). Dieetin valkuaispitoisuus oli K-ruokinnoilla keskimäärin 13,8 \% ja R-ruokinnoilla 14,6 \%. Säilörehun syönti muodostui kaikille ryhmille yhdenmukaiseksi ollen keskimäärin 4,93 kuiva-ainekiloa päivässä. Valkuaisen päivittäinen saanti muodostui R-ruokinnalla luonnollisesti suuremmaksi kuin K-ruokinnalla ( $\mathrm{P}<0,01,976$ vs. 1043 g). Kaikki hiehot saavuttivat tavoiteteuraspainonsa (Taulukko 2). Koe kesti keskimäärin 129 päivää (SD 20,6). RpRhiehoilla kasvatuskausi oli kuitenkin 18 päivää lyhyempi kuin RpK-hiehoilla (P>0,10). Yhtä hiehoa lääkittiin antibiootilla tammikuussa 2004 jalkavamman takia, muutoin hiehojen terveys oli hyvä.

Väkirehuseoksen runsaampi rypsipuristepitoisuus tehosti hiehojen päiväkasvua keskimäärin 184 g, kun vaikutus herneellä oli lievästi päinvastainen $(\mathrm{P}<0,05)$. Nettokasvuissa käsittelyiden välille ei muodostunut tilastollisesti merkitseviä eroja ollen keskimäärin 656 g/pv. Väkirehun runsaampi valkuaispitoisuuspitoisuus paransi kuitenkin hieman hiehojen nettokasvua $43 \mathrm{~g} / \mathrm{pv}(\mathrm{P}=0,12)$. Ruhojen lihakkuus oli keskimäärin 5,2. Kaikki ruhot rasvoittuivat runsaasti, keskimäärin 4,6, eikä dieetin runsaampi valkuaispitoisuus tässä kokeessa estänyt ruhojen rasvoittumista. Väkirehun määrä olisi voinut kenties olla hieman pienempi, kun käytössä oli sulavuudeltaan erinomainen säilörehu. Käytetyn säilörehun kaltaista rehua paremmin hiehoille sopisi kenties hieman heikomman D-arvon säilörehu tai jopa heinä, jolloin väkirehun runsaampi valkuaispitoisuus voisi tehostaa hiehojen kasvua ja estää ruhoja rasvoit- 
tumasta. Tällöin hiehot kasvaisivat todennäköisesti kuitenkin hitaammin ja kustannukset lisääntyisivät pidentyneen kasvatusajan myötä. Mielenkiintoista olisi myös ollut tarkastella tuotantotuloksia, mikäli kokeeseen olisi voinut lisätä koeryhmien lisäksi ruokinnat, joissa hiehot olisivat saaneet säilörehua ainoana rehuna vapaasti koko kasvatuskauden ja pelkällä ohralla täydennettynä. Rehun muuntosuhde muodostui RpR-hiehoille 0,89 KA-kiloa paremmaksi kuin RpK-hiehoille $(\mathrm{P}<0,05)$. Herneellä vaikutus oli päinvastainen. Myös lisäkasvukiloon käytetyn energian osalta tilanne oli samansuuntainen.

Taulukko 1. Rehujen syönti, energian, raakavalkuaisen, NDF:n, OIV:n ja PVT:n saanti.

\begin{tabular}{|c|c|c|c|c|c|c|c|c|}
\hline \multirow{2}{*}{$\begin{array}{l}\text { Valkuainen (V) } \\
\text { Pitoisuus (P) }\end{array}$} & \multicolumn{2}{|c|}{ Rypsipuriste } & \multicolumn{2}{|c|}{ Herne } & \multirow[t]{2}{*}{ SEM $^{1}$} & \multicolumn{3}{|c|}{ Merkitsevyys ${ }^{2}$} \\
\hline & $\mathrm{K}$ & $\mathrm{R}$ & $\mathrm{K}$ & $\mathrm{R}$ & & $\mathrm{V}$ & $\mathrm{P}$ & $\mathrm{V}^{*} \mathrm{P}$ \\
\hline \multicolumn{9}{|l|}{ Kuiva-aine, kg } \\
\hline Säilörehu & 4,97 & 5,10 & 4,96 & 4,98 & 0,155 & & & \\
\hline Ohra & 1,78 & 1,54 & 1,50 & 0,71 & & & & \\
\hline Rypsipuriste / herne & 0,167 & 0,456 & 0,481 & 1,228 & & & & \\
\hline Kivennäinen & 0,145 & 0,145 & 0,145 & 0,145 & & & & \\
\hline Yhteensä & 7,07 & 7,24 & 7,08 & 7,06 & 0,165 & & & \\
\hline \multicolumn{9}{|l|}{ Raakavalkuainen, g } \\
\hline Säilörehusta & 632 & 647 & 630 & 633 & 19,5 & & & \\
\hline Väkirehuista & 333 & 400 & 337 & 386 & 8,2 & & *** & \\
\hline Kivennäisestä & 10 & 10 & 10 & 10 & & & & \\
\hline Yhteensä & 975 & 1057 & 976 & 1029 & 21,7 & & ** & \\
\hline Orgaanista ainetta, kg & 6,50 & 6,65 & 6,51 & 6,51 & 0,153 & & & \\
\hline RY & 7,20 & 7,36 & 7,23 & 7,26 & 0,169 & & & \\
\hline NDF, g & 2606 & 2689 & 2553 & 2486 & 68,4 & 0 & & \\
\hline OIV, g & 662 & 693 & 662 & 672 & 15,2 & & & \\
\hline PVT, g & -144 & -108 & -144 & -106 & 4,2 & & $* * *$ & \\
\hline
\end{tabular}

${ }^{1}$ Keskiarvon keskivirhe.

2 о $\mathrm{P}<0,10$; * $\mathrm{P}<0,05$; ** $\mathrm{P}<0,01$; *** $\mathrm{P}<0,001$

Taulukko 2. Hiehojen kasvu, teurastulokset ja rehun muuntosuhde.

\begin{tabular}{|c|c|c|c|c|c|c|c|c|}
\hline \multirow{2}{*}{$\begin{array}{l}\text { Valkuainen (V) } \\
\text { Pitoisuus (P) }\end{array}$} & \multicolumn{2}{|c|}{ Rypsipuriste } & \multicolumn{2}{|c|}{ Herne } & \multirow[t]{2}{*}{$\mathrm{SEM}^{1}$} & \multicolumn{3}{|c|}{ Merkitsevyys $^{2}$} \\
\hline & K & $\mathrm{R}$ & $\mathrm{K}$ & $\mathrm{R}$ & & $\mathrm{V}$ & $\mathrm{P}$ & $\mathrm{V} * \mathrm{P}$ \\
\hline Kokeen alussa, kg & 258 & 258 & 258 & 258 & 9,2 & & & \\
\hline Kokeen lopussa, kg & 402 & 404 & 401 & 399 & 1,8 & 0 & & \\
\hline Teuraspaino, kg & 213,5 & 212,2 & 209,6 & 211,2 & 1,99 & & & \\
\hline Kuntoluokka alussa & 2,99 & 2,92 & 2,84 & 2,92 & 0,044 & 0 & & 0 \\
\hline Kuntoluokka lopussa & 3,43 & 3,43 & 3,33 & 3,41 & 0,088 & & & \\
\hline Kokeen kesto, pv & 134 & 116 & 124 & 127 & 9,0 & & & \\
\hline Kasvu kokeen aikana, g/ & v1075 & 1259 & 1156 & 1126 & 51,3 & & & * \\
\hline Nettokasvu ${ }^{3}$ & 635 & 718 & 654 & 656 & 26,7 & & & \\
\hline Teuras-\% & 53,1 & 52,6 & 52,3 & 53,0 & 0,44 & & & \\
\hline Lihakkuus $^{4}$ & 5,0 & 5,4 & 5,2 & 5,2 & 0,20 & & & \\
\hline Rasvaisuus $^{5}$ & 4,8 & 4,7 & 4,4 & 4,6 & 0,28 & & & \\
\hline \multicolumn{9}{|l|}{ Rehun muuntosuhde } \\
\hline KA kg/lisäkasvu-kg & 6,63 & 5,74 & 6,12 & 6,33 & 0,227 & & & * \\
\hline KA kg/nettokasvu-kg & 11,18 & 10,08 & 10,85 & 10,80 & 0,333 & & o & \\
\hline RY/lisäkasvu-kg & 6,74 & 5,83 & 6,25 & 6,51 & 0,231 & & & * \\
\hline RY/nettokasvu-kg & 11,37 & 10,25 & 11,09 & 11,11 & 0,342 & & & \\
\hline RV g/lisäkasvu-kg & 913 & 838 & 843 & 924 & 32,4 & & & * \\
\hline RV g/nettokasvu-kg & 1541 & 1472 & 1496 & 1577 & 48,3 & & & \\
\hline
\end{tabular}

${ }^{1}$ Keskiarvon keskivirhe. ${ }^{2}$ o $\mathrm{P}<0,10$; * $\mathrm{P}<0,05$; ** $\mathrm{P}<0,01$; *** $\mathrm{P}<0,001$.

${ }^{3}$ Nettokasvua laskettaessa alkupainon teuras-\%:na käytetty 50. ${ }^{4}$ EUROP-luokitus: $\mathrm{O}-=4, \mathrm{O}=5, \mathrm{O}+=6$.

${ }^{5}$ EUROP-luokitus: 2=vähäinen, 3=keskinkertainen, 4=rasvainen.

Ruokintojen vaikutus arvopalasaantoihin oli marginaalinen, sillä ainoastaan kulmapaistin saantoon valkuaislähteellä oli vaikutusta ( $\mathrm{P}<0,05$, rypsipuriste 3,435 vs. herne 3,744 , Taulukko 3 ). Rasvaa rypsipuristetta saaneen hiehon ruhonpuolikkaasta leikattiin keskimäärin kaksi kiloa enemmän kuin 
hernettä saaneen hiehon ruhonpuolikkaista $(\mathrm{P}>0,10)$. Väkirehun alhaisempi valkuaispitoisuus rypsipuristeella paransi lihan mehukkuutta, mutta herneellä vaikutus oli päinvastainen $(\mathrm{P}<0,05)$. Ulkofileen loppu-pH oli keskimäärin 5,51 (SD 0,11) ja kaikkien ruhojen ulkofileen loppu-pH oli alle 6,00 eli tervalihaprosentti oli 0 .

Taulukko 3. Leikkuusaannot ja ulkofileen aistinvarainen laatu.

\begin{tabular}{|c|c|c|c|c|c|c|c|c|}
\hline \multirow{2}{*}{$\begin{array}{l}\text { Valkuainen (V) } \\
\text { Pitoisuus (P) }\end{array}$} & \multicolumn{2}{|c|}{ Rypsipuriste } & \multicolumn{2}{|c|}{ Herne } & \multirow[t]{2}{*}{$\mathrm{SEM}^{1}$} & \multicolumn{3}{|c|}{ Merkitsevyys $^{2}$} \\
\hline & $\mathrm{K}$ & $\mathrm{R}$ & $\mathrm{K}$ & $\mathrm{R}$ & & $\mathrm{V}$ & $\mathrm{P}$ & $\mathrm{V}^{*} \mathrm{P}$ \\
\hline \multicolumn{9}{|c|}{ Ruhon puolikas, kg } \\
\hline Sisäfile & 1,377 & 1,437 & 1,367 & 1,323 & 0,0679 & & & \\
\hline Ulkofile & 3,461 & 3,513 & 3,625 & 3,694 & 0,1528 & & & \\
\hline Sisäpaisti & 4,025 & 4,060 & 4,232 & 4,241 & 0,1172 & & & \\
\hline Ulkopaisti & 4,057 & 4,078 & 4,144 & 4,087 & 0,1669 & & & \\
\hline Paahtopaisti & 2,141 & 2,046 & 2,120 & 2,126 & 0,0666 & & & \\
\hline Pyöröpaisti & 1,529 & 1,503 & 1,504 & 1,476 & 0,0585 & & & \\
\hline Kulmapaisti & 3,359 & 3,511 & 3,685 & 3,803 & 0,1112 & * & & \\
\hline Rasvat & 24,544 & 23,104 & 21,704 & 21,924 & 1,3100 & & & \\
\hline \multicolumn{9}{|c|}{ Ulkofileen laatuanalyysit, aistinvarainen $\operatorname{arvio}^{3}$} \\
\hline Mureus & 5,5 & 4,9 & 4,7 & 5,3 & 0,47 & & & \\
\hline Mehukkuus & 5,6 & 4,8 & 4,8 & 5,2 & 0,28 & & & $*$ \\
\hline Maku & 4,9 & 4,9 & 4,7 & 4,9 & 0,28 & & & \\
\hline Konsistenssi $^{4}$ & 5,8 & 7,2 & 9,9 & 7,2 & 1,45 & & & \\
\hline Ulkofileen $\mathrm{pH}_{24}$ & 5,50 & 5,49 & 5,59 & 5,51 & 0,055 & & & \\
\hline
\end{tabular}

${ }^{1}$ Keskiarvon keskivirhe.

2 o $\mathrm{P}<0,10 ; * \mathrm{P}<0,05 ; * * \mathrm{P}<0,01 ; * * * \mathrm{P}<0,001$.

${ }^{3}$ Aistinvarainen arvio: asteikko 1-7, esim. 7=erittäin murea.....1=erittäin sitkeä.

${ }^{4}$ Vastus lihapalaa leikatessa.

\section{Johtopäätökset}

Hiehojen kasvu kokeessa oli hyvä, keskimäärin 1125 g päivässä, ja ne saavuttivat teuraspainotavoitteensa 210 kiloa keskimäärin 10,5 kuukauden iässä. Kumpikaan väkirehun valkuaispitoisuuksista ei estänyt ruhojen rasvoittumista. Kokeessa käytetty säilörehu oli sulavuudeltaan erittäin hyvää. Arvot olivat tyypillisiä ensimmäisen niiton arvoja Pohjois-Karjalassa kesäkuussa 2003. Hyvän säilörehun merkitys hiehojen tehokkaaseen kasvuun tuli kokeessa hyvin esille. Käytetyn säilörehun raakavalkuaispitoisuus oli suhteellisen alhainen, keskimäärin 12,8 \% kuiva-ainekilossa. Dieettien kokonaisvalkuaispitoisuus jäi alle 15 \% vaikka väkirehuseos sisälsi 20 \% raakavalkuaista. Dieetin väkirehuprosentti oli keskimäärin 28 ja tältä osin kaikki ruokinnat täyttivät luonnonmukaisen tuotannon vaatimuksen väkirehu-karkearehu-suhteesta. Rypsipuristeen suurempi pitoisuus väkirehussa paransi hiehojen päiväkasvua $184 \mathrm{~g}$ ja se osoittautui hernettä paremmaksi valkuaislähteeksi. Herneen saatavuus ja hinta määrännevät käytännössä sen käyttömahdollisuudet lihanautojen ruokinnassa.

Kiitokset MTT:n emolehmänavetan, Kiteen koulutilan navetan ja opetusteurastamon henkilökunnalle sujuvasta ja huolellisesta yhteistyöstä kokeen toteutuksessa. Kiitokset Mildola Oy:lle kokeeseen toimitetusta rypsipuristeesta.

\section{Kirjallisuus}

Friedel, K. 1990. Die Schätzung des energetischen Futterwertes von Grobfutter mit Hilfe einer Cellulasemethode.[The estimation of the energetic feeding value of roughages by means of a cellulase method]. Wissenschaftliche Zeitschrift Universitet Rostock, N-Reihe 39: 78-86.

Heikkilä, T. \& Toivonen, V. 1997. Herne ja rypsirouhe lehmien valkuaisrehuna säilörehuruokinnalla. Kotieläintieteen päivät 1997. MKL:n julkaisuja no 914: 187-190.

\section{Http://www.mtt.fi/tutkimus/talous/talous.html}

Kallinen, A. 2004. Sähköpostitiedonanto 31.1.2005. Suomen Gallup Elintarviketieto Oy.

Khalili, H., Kuusela, E., Suvitie, M. \& Huhtanen, P. 2002. Effect of protein and energy supplements on milk production in organic farming. Anim. Feed Sci. Technol. 98, 1-2: 103-119.

Lowman, B.G., Scott, N.A. \& Somerville, S.H. 1976. Condition scoring of cattle. The East of Scotland College of Agriculture, Bulletin No.6. 
Manninen, M., Nykänen, A. \& Musikka, T. 2004a. Vehnä-rehuvirnakokoviljasäilörehua lihahiehoille. Käytännön Maamies 11: 46-48.

Manninen, M. \& Ojajärvi, P. 2000. Rypsitäydennyksen vaikutus kokoviljasäilörehuruokinnalla hereford- ja ayrshire-hiehojen kasvuun sekä ruhon ja lihan laatuun. Kotieläintieteen päivät 2000. MKL:n julkaisuja no 952. p. 169-172.

Manninen, M., Ojajärvi, P. \& Suvitie, M. 2004b. Kaura-rehuvirnasäilörehu teurashiehojen ruokinnassa. In: Maataloustieteen Päivät 2004, 12-13.1.2004 Viikki, Helsinki. Suomen Maataloustieteellisen Seuran tiedote no 19. http://www.agronet.fi/maataloustieteellinenseura/julkaisut/posterit04/kr11.pdf

Manninen, M., Virkajärvi, P., Ojajärvi, P., Jauhiainen, L. \& Suvitie, M. 2002. Toisen laidunkauden vaikutus teuraaksi kasvatettavien hf-hiehojen kasvuun sekä ruhon ja lihan laatuun. In: Maataloustieteen päivät 9.10.1.2002. Kotieläintiede. MKL:n julkaisuja no 977. p. 188-191.

MTT. 2004. Rehutaulukot ja ruokintasuositukset [verkkojulkaisu]. Jokioinen: Maa- ja elintarviketalouden tutkimuskeskus. Julkaistu 30.6.2004. Saatavissa: http://www.agronet.fi/rehutaulukot/. URN:NBN:fi-fe20041449.

Rinne, M., Harinen, T., Asikainen, U., Huhta, H. \& Aspila, P. 1998. Ruokinnan voimakkuuden vaikutus teurashiehojen kasvuun. Kotieläintieteen päivät 1998. MKL:n julkaisuja no 924. p. 293-296.

Rinne, M. \& Ojajärvi, P. 1998. Ohra ja rypsirouhe rajoitetusti säilörehua saaneiden teurashiehojen väkirehuna. Kotieläintieteen päivät 1998. MKL:n julkaisuja no 924. p. 297-302.

Root, T. 1995. Valkuaisen pötsihajoavuuden merkitys lihanaudan ruokinnassa. Kotieläintieteen päivät 1995. MKL:n julkaisuja no 888. p. 165-169.

SAS. 1999. SAS/STAT User's Guide, Version 8, Cary, NC: SAS Institute Inc. 3809 p.

TIKE. 2003. Maatilatilastollinen vuosikirja 2003. Maa- ja metsätalousministeriön tietopalvelukeskus. Helsinki. $266 \mathrm{p}$.

Van Soest, P.J., Robertson, J.B. \& Lewis, B.A. 1991. Methods for dietary fiber, neutral detergent fiber and nonstarch polysaccharides in relation to animal nutrition. J. Dairy Sci. 74: 3583-3597.

Vanhatalo, A., Ahvenjärvi, S. \& Jaakkola, S. 2004. Metabolic and production responses in dairy cows fed peas or rapeseed meal on grass silage based diet. In: The X International symposium on ruminant physiology : August 30th to September 4th 2004, Copenhagen, Denmark : short papers. J. Anim. Feed Sci. 13, Suppl. 1: 231234. 